\title{
Evaluation of Different Storage Structures on Potato Tuber Moth Damage and Potato Shelf Life at Bako, West Shoa, Ethiopia
}

\section{Ahmed Ibrahim*}

Bako Agricultural Research Center, Post Box: 03, Bako, West Shoa, Ethiopia

\begin{tabular}{|c|c|}
\hline \multirow{16}{*}{$\begin{array}{l}\text { Abstract } \\
\text { The experiment was conducted for two cropping (2009/2010 and 2011/2012) seasons at Bako } \\
\text { Agricultural Research Center and one cropping season (2013) at Legaya around Bako on the } \\
\text { farmers field. Six different storage structures (pit storage, storage in mud blocket, above } \\
\text { ground storage (circular form of mat), storage inside gotera, simple silo of land constructed } \\
\text { above the ground (investigated by Holeta Research Center) and storage inside residue of "tef" } \\
\text { used by farmers of western Oromia (check)) were evaluated against potato tuber moth damage } \\
\text { and potato shelf life. The experiment was laid out in randomized complete block design with } \\
\text { three replications. Potato local variety "Menagesha" was purchased from farmers and used for } \\
\text { the experiment. Data was collected for percent weight of tubers infested and damaged by } \\
\text { potato tuber moth, percent weight of potato tubers rotten by diseases, percent weight of tubers } \\
\text { produced sprouting, and percent weight of tubers normal. Percent weight of tubers infested and } \\
\text { damaged by potato tuber moth significantly ( } P<0.05) \text { higher in the storage inside residue of tef } \\
\text { than the others. Percent weight of tuber damaged by diseases significantly higher in all of the } \\
\text { treatments and non significant differences were recorded among them. Percent weights of } \\
\text { tubers produce sprout significantly ( } P<0.05) \text { higher in pit, cereal grain storage (gotera) and mud } \\
\text { blocket than the other treatments. Percent weight of tubers normal significantly ( } P<0.05 \text { ) higher } \\
\text { in the mud blocket storage, mat storage, and simple silo of land constructed above the ground } \\
\text { (investigated by Holeta Research Center). It can be conclude that mud blocket storage, mat } \\
\text { storage, simple silo of land (investigated by Holeta Research Center) can be used to protect } \\
\text { consumption potatoes from potato tuber moth and increases shelf life of potatoes for about } \\
\text { three months and ten days. }\end{array}$} & \\
\hline & ticle History: \\
\hline & Received : 18-04-2015 \\
\hline & : 21-06-2015 \\
\hline & Accepted : 23-06-2015 \\
\hline & \\
\hline & \\
\hline & $\mathrm{P}$ \\
\hline & 0 \\
\hline & $\mathrm{N}$ \\
\hline & \\
\hline & \\
\hline & ${ }^{*}$ Corresponding Author: \\
\hline & \\
\hline & \\
\hline & \\
\hline
\end{tabular}

\section{INTRODUCTION}

Potato is the second most important tuber crop grown in Ethiopia next to Enset in terms of area coverage (Solomon, 1985). It is one of the major food crops grown in high lands and mid altitude of western Oromia and used for food and income security.

Like cereal grains, it requires appropriate storage to prolong the shelf life and utilize at required time. The primary aim of storing food tubers are to ensure a uniform supply of food tubers through out the year, to provide a reserve for contingences and to secure on high prices. So for one or more of the above reason potato tubers are often stored for more than two months. But there are biotic and abiotic factors that deteriorate the produce in the storage. Potato tuber moth (PTM) is one of the biotic factors that destruct the tubers in the storage. Anonymous, (1980) reported that storage losses due to Potato tuber moth (PTM) is varies from $30-70 \%$ in India and as high as $86 \%$ in Tunisia, Algeria and Turkey. According to Adhanom et al. (1985), in Ethiopia damage to potato by this pest can reach up to $91 \%$ in 90 days.

The tubers are living organisms where there is a continuous flow of moisture due to respiration leading to loss in specific gravity (solid contents) that terminates in loss of marketability and food value. So harvested tubers should be covered immediately after harvest to prevent ovipositor site of the moth. Palacious and Cisneros (1997) suggested that harvested tuber should not remain exposed to ovipositing females over night and if they couldn't be stored immediately, tubers should be at least be covered, other wise the infestation level could reach $60 \%$ with in a few days.

In our cases, no attempt has been done so far to over come the problem, specifically in western Oromia. Even though, it is not practiced in most part of our country, there are numerous cultural practices applied to reduce the post harvest loses in eastern parts of Ethiopia (Hararghe area, personal observation). The practices include underground storage (pit), above ground storage (constructed from mud biloket), storage inside mat and cereal grain gotera. Utilization of crop residue and leaving the tubers in the soil are another practices used by the farmers of western Oromia. So the purpose of potato storage is to maintain the tubers in their most edible and salable condition and to provide a uniform flow of tubers through out the years. Good storage (Smith, 1977) should 


\section{Ahmed lbrahim}

prevent large accumulation of sugar and other constituent, which result in dark color in processing and also prevents excessive loss of moisture, development of rots and excessive sprout growth. Therefore, the farmers' traditional methods should be evaluated for efficacy after which it will be either encouraged or else improved. Thus the objective of the experiment was to evaluate the effect of different storage structures on the potato tuber moth damage and the shelf life of tubers.

\section{MATERIALS AND METHODS}

The experiment was conducted at Bako Agricultural Research Center for two years (2009/2010 and 2011/2012). The Center lies at $9^{\circ} 6^{\prime} \mathrm{N}$ latitude and $37^{\circ} 09^{\circ} \mathrm{E}$ longitude, $260 \mathrm{~km}$ west of Addis Ababa, at an altitude of 1650 m.a.s.l. The area is characterized by warm and humid climate. The annual average rainfall and relative humidity were $1341 \mathrm{~mm}$ and $60.11 \%$ respectively during the study period. The average minimum and maximum atmospheric temperatures of the area during the study period were $12.58^{\circ} \mathrm{C}$ and $27.21^{\circ} \mathrm{C}$ respectively.

Six different storage structures of potatoes were evaluated against potato tuber moth damage and potato shelf life. Total of eighteen storage structures of potatoes were constructed at the Bako Agricultural Research Center from the local materials. Potato variety "Menagesha" was purchased from the farmers and used for the experiment. For each treatment 1.5 quintals (150 $\mathrm{kg}$ ) of potatoes were used. Twenty-seven (27) quintals of potato were used to conduct a year experiment. Each treatment was laid out in a randomized complete block design with three replications. Data was collected on percent weight of tubers infested by potato tuber moth (PTM), percent weight of tubers damaged by potato tuber moth (PTM), percent weight of tubers rotten by diseases, percent weight of tubers produce sprout and percent weight of tubers normal at an interval of 20 days for about four consecutive months during each experimental year. Combined analysis was done for the two-year data using SAS Version 6.12 computer software.

\section{RESULTS AND DISCUSSION}

Effects of different storage structures on percent weight of tubers infested and damaged by potato tuber moth (PTM), percent weight of tubers produced sprout, percent weight of tubers normal and percent weight of tubers damaged by diseases are indicated in Table1. Percent weights of tubers infested and damaged by Potato tuber moth $(\mathrm{PTM})$ were significantly $(\mathrm{P}<0.05)$ higher in the untreated check than the other treatments. Non-significant differences were observed among the other treatments except for the untreated check. Percent weight of tubers damaged by diseases significantly $(P<0.05)$ very high in all of the treatments and nonsignificant differences were recorded among them. Significantly $(P<0.05)$ lower percent weight of tubers produce sprout was observed in mud blocket storage, above ground storage (circular form of mat used), simple silo of land constructed above the ground and in the
Sci. Technol. Arts Res. J., April-June 2015, 4(2): 64-67

untreated check than the other treatments and insignificant differences were recorded among them. Percent weight of tubers normal was significantly $(0.05)$ higher in mud blocket storage, above ground storage (circular form of mat used) and simple silo of land constructed above the ground than the other treatments and non-significant differences were recorded among them.

Appropriate storage structures are crucial to store consumption potatoes in order to minimize losses caused by potato tuber moth and increased the shelf lies of the potato tubers. Percent weights of tubers infested and damaged by potato tuber moth significantly $(P<0.05)$ higher in the untreated check than the other storage structures. These are in agreement with Palacious and Cisneros (1997) suggested that, harvested tuber should not remain exposed to ovipositing females over night and if they couldn't be stored in appropriate storage structures immediately, otherwise the infestation and damage level could reach high level within a few days. The current results also in agreement with the farmer's practices in eastern part of Ethiopia, Hararghe Deder wored area (personal observation). The farmers in these areas used pit storage, storage in mud blocket, above ground storage (circular form of mat) and storage inside cereal grain gotera to minimize the losses and damage caused by potato tuber moth. In the eastern parts of Ethiopia, "Deder woreda" areas most of the framers used below ground storage to extend the shelf life of the potatoes. Smith (1997) also reported that, most modern potato storage is of the bank, above ground or below ground with super structure. Tindal (1983) reported that, it is possible to reduce the post harvest losses of potato by storing in the pit or clamps dug in the ground to $75 \mathrm{~cm}$ deep, $2.5 \mathrm{~cm}$ long and $1 \mathrm{~m}$ wide, and should be sited in cool preferably shaded area. On the other hands, our results did not agree with the farmer's practices of eastern Ethiopia, deder areas in case of percent weight of tubers produce sprout and normal obtained from below ground storage and storage inside cereal grain gotera. Probably because of soil type and environmental conditions of experimental areas. On the other hands the finding confirmed that significantly $(P<0.05)$ very low percent weight of tubers produced sprout and higher percent weight of tubers normal were rerecorded in mud blocket storage, above ground storage (circular form of mat used) and simple silo of land constructed above the ground (Investigated by Holeta Research Center). Good storage structures (Smith, 1977; Varlag Paul Parey, 1973) should prevent large accumulation of sugar and other constituent, which result in dark color in processing and also prevents excessive loss of moisture, development of rots and excessive sprout growth. Therefore storage in mud blocket, above ground storage (circular form of mat) and simple silo of land constructed above the ground (investigated by Holeta Research Center) can be used to prevent damage caused by potato tuber moth and increase the shelf-life of the tubers. 
Table 1: Effects of different storage structures on percent weight of tubers infested and damaged by potato tuber moth, percent weight of tubers damaged by diseases, percent weight of tuber produce sprout and percent weight of tubers normal at Bako (combined ANOVA for the data of 2009/2010 and 2011/2012 cropping seasons).

\begin{tabular}{|c|c|c|c|c|c|c|}
\hline $\begin{array}{l}\text { Trt. } \\
\text { no. }\end{array}$ & Treatments & $\begin{array}{c}\% \text { weight } \\
\text { (kg) of } \\
\text { tubers } \\
\text { infested } \\
\text { by PTM }\end{array}$ & $\begin{array}{c}\text { \% weight (kg) } \\
\text { of tubers } \\
\text { damaged by } \\
\text { PTM }\end{array}$ & $\begin{array}{l}\% \text { weight (kg) } \\
\text { of tubers } \\
\text { damaged by } \\
\text { diseases and } \\
\text { others }\end{array}$ & $\begin{array}{l}\% \text { weight } \\
\text { (kg) } \\
\text { of tubers } \\
\text { produce } \\
\text { sprout }\end{array}$ & $\begin{array}{c}\% \\
\text { weight of } \\
\text { tubers normal }\end{array}$ \\
\hline 1 & Below ground storage (pit) & $1.38 \pm 0.47 \mathrm{~b}$ & $2.81 \pm 0.17 \mathrm{~b}$ & $2.17 \pm 0.37 \mathrm{a}$ & $36.57 \pm 1.88 \mathrm{a}$ & $50.88 \pm 1.76 \mathrm{c}$ \\
\hline 2 & Storage in mud blocket & $1.42 \pm 0.31 \mathrm{~b}$ & $2.07 \pm 0.20 \mathrm{~b}$ & $1.48 \pm 0.19 \mathrm{a}$ & $1.23 \pm 0.24 \mathrm{c}$ & $87.41 \pm 1.53 \mathrm{a}$ \\
\hline 3 & $\begin{array}{l}\text { Above ground storage } \\
\text { (Circular form of mat) }\end{array}$ & $1.60 \pm 0.24 b$ & $2.42 \pm 0.29 \mathrm{~b}$ & $1.87 \pm 0.40 \mathrm{a}$ & $1.71 \pm 0.34 \mathrm{c}$ & $88.04 \pm 0.54 a$ \\
\hline 4 & $\begin{array}{l}\text { Storage inside gotera (cereal } \\
\text { grainStorage) } \\
\text { Simple silo of land constructed }\end{array}$ & $1.79 \pm 0.31 b$ & $2.82 \pm 0.71 \mathrm{~b}$ & $1.57 \pm 0.22 \mathrm{a}$ & $30.31 \pm 1.70 b$ & $58.37 \pm 2.48 b$ \\
\hline 5 & $\begin{array}{l}\text { above the ground (Investigated } \\
\text { by Holleta Research Center) } \\
\text { Storage inside residue of tef }\end{array}$ & $1.06 \pm 0.17 \mathrm{~b}$ & $1.76 \pm 0.22 \mathrm{~b}$ & $1.46 \pm 0.22 \mathrm{a}$ & $1.64 \pm 0.41 \mathrm{c}$ & $87.92 \pm 0.67 \mathrm{a}$ \\
\hline 6 & $\begin{array}{l}\text { used by farmers of western } \\
\text { Oromia (control) }\end{array}$ & $10.39 \pm 1.01 \mathrm{a}$ & $23.29 \pm 0.54 \mathrm{a}$ & $1.52 \pm 0.30 \mathrm{a}$ & $1.44 \pm 0.13 c$ & $56.44 \pm 1.13 b$ \\
\hline & CV (\%) & 8.36 & 14.18 & 39.78 & 24.35 & 4.43 \\
\hline & Lsd & 1.862 & 1.497 & 1.137 & 5.022 & 5.493 \\
\hline
\end{tabular}

Potato Tuber Moth (PTM)

Table 2: Effects of different storage structures on percent weight of tubers infested and damaged by potato tuber moth, percent weight of tubers damaged by diseases, percent weight of tubers produce sprout and percent weight of tubers normal at Bako (combined ANOVA for the data of 2009/2010 cropping season).

\begin{tabular}{|c|c|c|c|c|c|c|}
\hline $\begin{array}{l}\text { Trt. } \\
\text { no. }\end{array}$ & Treatments & $\begin{array}{c}\text { \% weight } \\
\text { (kg) of } \\
\text { tubers infested } \\
\text { by PTM }\end{array}$ & $\begin{array}{l}\% \text { weight }(\mathbf{k g}) \\
\text { of tubers } \\
\text { damaged by } \\
\text { PTM }\end{array}$ & $\begin{array}{c}\% \text { weight } \\
\text { (kg) of tubers } \\
\text { damaged by } \\
\text { diseases and } \\
\text { others }\end{array}$ & $\begin{array}{l}\% \text { weight }(\mathbf{k g}) \\
\text { of tubers } \\
\text { produce } \\
\text { sprout }\end{array}$ & $\begin{array}{l}\% \text { weight of } \\
\text { tubers normal }\end{array}$ \\
\hline 1 & Below ground storage (pit) & $1.82 \pm 0.89 \mathrm{~b}$ & $2.92 \pm 0.20 \mathrm{~b}$ & $2.15 \pm 0.79 \mathrm{a}$ & $38.16 \pm 3.17 \mathrm{a}$ & $48.34 \pm 0.87 \mathrm{c}$ \\
\hline 2 & Storage in mud blocket & $1.98 \pm 0.40 \mathrm{~b}$ & $1.82 \pm 0.25 \mathrm{~b}$ & $1.61 \pm 0.24 \mathrm{a}$ & $1.03 \pm 0.48 \mathrm{c}$ & $86.17 \underline{+} 2.95 \mathrm{a}$ \\
\hline 3 & $\begin{array}{l}\text { Above ground storage } \\
\text { (Circular form of mat) }\end{array}$ & $1.71 \pm 0.32 b$ & $2.06 \pm 0.39 \mathrm{~b}$ & $2.52 \pm 0.57 \mathrm{a}$ & $1.16 \pm 0.18 \mathrm{c}$ & $88.99 \pm 0.45 a$ \\
\hline 4 & $\begin{array}{l}\text { Storage inside gotera (cereal } \\
\text { Grain Storage) }\end{array}$ & $2.18 \pm 0.23 b$ & $4.05 \pm 0.79 b$ & $1.75 \pm 0.23 \mathrm{a}$ & $30.31 \pm 3.63 b$ & $54.12 \pm 2.39 \mathrm{bc}$ \\
\hline 5 & $\begin{array}{l}\text { Simple silo of land constructed } \\
\text { above the ground (Investigated } \\
\text { by Holleta Research Center) } \\
\text { Storage inside residue of tef }\end{array}$ & $1.43 \pm 0.13 b$ & $2.00 \pm 0.05 \mathrm{~b}$ & $1.11 \pm 0.26 \mathrm{a}$ & $1.09+0.19 \mathrm{c}$ & $88.29 \pm 1.08 \mathrm{a}$ \\
\hline 6 & $\begin{array}{l}\text { used by farmers of western } \\
\text { Oromia (control) }\end{array}$ & $11.16 \pm 1.64 \mathrm{a}$ & $23.41 \pm 1.18 \mathrm{a}$ & $1.45 \pm 0.36 a$ & $1.58 \pm 0.12 c$ & $57.23 \pm 2.21 \mathrm{~b}$ \\
\hline & CV (\%) & 17.62 & 17.23 & 40.18 & 12.76 & 4.31 \\
\hline
\end{tabular}

Similar letters within the same column are not significantly different from each other at $5 \%$ probability level

(SNK range test); Potato Tuber Moth (PTM)

Table 3: Effects of different storage structures on percent weight of tubers infested and damaged by potato tuber moth, percent weight of tubers damaged by diseases, percent weight of tubers produce sprout and percent weight of tubers normal at Bako (2011/2012 cropping season).

\begin{tabular}{|c|c|c|c|c|c|c|}
\hline $\begin{array}{l}\text { Trt. } \\
\text { no. }\end{array}$ & Treatments & $\begin{array}{c}\text { \% weight } \\
\text { (kg) of } \\
\text { tubers infested } \\
\text { by PTM }\end{array}$ & $\begin{array}{c}\% \text { weight }(\mathbf{k g}) \\
\text { of tubers } \\
\text { damaged by } \\
\text { PTM }\end{array}$ & $\begin{array}{c}\% \text { weight } \\
\text { (kg) of tubers } \\
\text { damaged by } \\
\text { diseases and } \\
\text { others }\end{array}$ & $\begin{array}{l}\text { \% weight } \\
\text { (kg) } \\
\text { of tubers } \\
\text { produce } \\
\text { sprout }\end{array}$ & $\begin{array}{l}\% \text { weight } \\
\text { of } \\
\text { tubers } \\
\text { normal }\end{array}$ \\
\hline 1 & Below ground storage (pit) & $0.93+0.37 \mathrm{~b}$ & $2.71 \pm 0.32 \mathrm{~b}$ & $2.19+0.26 \mathrm{a}$ & $34.98+2.29 \mathrm{a}$ & $53.40+2.89 \mathrm{c}$ \\
\hline 2 & \multirow{2}{*}{$\begin{array}{l}\text { Storage in mud blocket } \\
\text { Above ground storage } \\
\text { (Circular form of mat) }\end{array}$} & $0.86 \pm 0.09 \mathrm{~b}$ & $2.32 \pm 0.28 \mathrm{~b}$ & $1.35 \pm 0.33 \mathrm{a}$ & $1.4 \pm 0.17 \mathrm{c}$ & $88.66 \pm 1.22 \mathrm{a}$ \\
\hline 3 & & $1.49 \pm 0.41 b$ & $2.78 \pm 0.38 \mathrm{~b}$ & $1.22 \pm 0.26 \mathrm{a}$ & $2.26 \pm 0.49 \mathrm{c}$ & $87.09 \pm 0.62 \mathrm{a}$ \\
\hline 4 & $\begin{array}{l}\text { Storage inside gotera (cereal } \\
\text { grainStorage) }\end{array}$ & $1.39 \pm 0.53 b$ & $1.58 \pm 0.59 \mathrm{~b}$ & $1.39 \pm 0.39 a$ & $30.32 \pm 1.18 b$ & $62.63 \pm 2.64 \mathrm{~b}$ \\
\hline 5 & $\begin{array}{l}\text { Simple silo of land constructed } \\
\text { above the ground (Investigated } \\
\text { by Holleta Research Center) }\end{array}$ & $0.70 \pm 0.06 \mathrm{~b}$ & $1.52 \pm 0.42 b$ & $1.82 \pm 0.24 \mathrm{a}$ & $2.19 \pm 0.71 \mathrm{c}$ & $87.54 \pm 0.97 a$ \\
\hline 6 & $\begin{array}{l}\text { Storage inside residue of tef } \\
\text { used by farmers of western } \\
\text { Oromia (control) }\end{array}$ & $9.62 \pm 1.35 \mathrm{a}$ & $23.16 \pm 0.20 \mathrm{a}$ & $1.59 \pm 0.57 \mathrm{a}$ & $1.29 \pm 0.24 \mathrm{c}$ & $55.65 \pm 0.95 c$ \\
\hline & CV (\%) & 38.50 & 9.60 & 39.17 & 15.20 & 4.55 \\
\hline
\end{tabular}

Similar letters within the same column are not significantly different from each other at $5 \%$ probability level (SNK range test) ; Potato Tuber Moth (PTM) 
Table 4: Effects of different storage structures on percent weight of tubers infested and damaged by potato tuber moth, percent weight of tubers damaged by diseases, percent weight of tubers produce sprout and percent weight of tubers normal at legaya around Bako on the farmers field (2013 cropping season).

\begin{tabular}{|c|c|c|c|c|c|c|}
\hline $\begin{array}{l}\text { Trt. } \\
\text { no. }\end{array}$ & Treatments & $\begin{array}{c}\text { \% weight } \\
\text { (kg) of } \\
\text { tubers infested } \\
\text { by PTM }\end{array}$ & $\begin{array}{l}\% \text { weight }(\mathbf{k g}) \\
\text { of tubers } \\
\text { damaged by } \\
\text { PTM }\end{array}$ & $\begin{array}{c}\% \text { weight } \\
\text { (kg) of tubers } \\
\text { damaged by } \\
\text { diseases and } \\
\text { others }\end{array}$ & $\begin{array}{l}\text { \% weight } \\
\text { (kg) } \\
\text { of tubers } \\
\text { produce } \\
\text { sprout }\end{array}$ & $\begin{array}{l}\% \text { weight } \\
\text { of } \\
\text { tubers } \\
\text { normal }\end{array}$ \\
\hline 1 & Storage in mud blocket & $1.07 \pm 0.14 \mathrm{c}$ & $1.54 \pm 0.16 \mathrm{c}$ & $1.41+0.07 \mathrm{a}$ & $3.56 \pm 0.17 b$ & $83.23 \pm 1.07 \mathrm{a}$ \\
\hline 2 & $\begin{array}{l}\text { Above ground storage } \\
\text { (Circular form of mat) } \\
\text { Simple silo of land constructed }\end{array}$ & $1.14 \pm 0.65 b$ & $1.75 \pm 0.42 \mathrm{c}$ & $2.04 \pm 0.30 \mathrm{a}$ & $1.74 \pm 0.18 \mathrm{c}$ & $79.14 \pm 0.35 a$ \\
\hline 3 & $\begin{array}{l}\text { above the ground (Investigated } \\
\text { by Holleta Research Center) }\end{array}$ & $0.75 \pm 0.07 \mathrm{c}$ & $1.74 \pm 0.32 \mathrm{c}$ & $1.67 \pm 0.17 \mathrm{a}$ & $1.07 \pm 0.57 \mathrm{c}$ & $90.54 \pm 0.68 \mathrm{a}$ \\
\hline 4 & $\begin{array}{l}\text { Storage inside gotera (cereal } \\
\text { grain Storage }\end{array}$ & $5.87 \pm 0.14 b$ & $5.21 \pm 0.35 b$ & $1.86 \pm 0.18 a$ & $1.02 \pm 0.64 \mathrm{c}$ & $78.14 \pm 0.76 \mathrm{~b}$ \\
\hline 5 & Below ground storage (pit) & $1.02 \pm 0.02 \mathrm{c}$ & $1.02 \pm 0.21 \mathrm{c}$ & $1.47 \pm 0.32$ a & $10.24 \pm 0.61 \mathrm{a}$ & $64.41 \pm 0.87 c$ \\
\hline 6 & $\begin{array}{l}\text { Storage inside residue of tef } \\
\text { used by farmers of western } \\
\text { Oromia (control) }\end{array}$ & $8.24 \pm 1.01 \mathrm{a}$ & $35.01 \pm 0.20 \mathrm{a}$ & $1.08 \pm 0.47 \mathrm{a}$ & $1.37 \pm 0.17 \mathrm{c}$ & $62.14 \pm 0.77 c$ \\
\hline & CV\% & 12.45 & 14.01 & 28.47 & 8.45 & 19.47 \\
\hline
\end{tabular}

Similar letters within the same column are not significantly different from each other at $5 \%$ probability level (SNK range test); Potato Tuber Moth (PTM)

\section{CONCLUSIONS}

The experiment was conducted at Bako agricultural research center west shoa, Bako, Ethiopia. The studies were made to evaluate different storage structures against potato tuber moth damage and potato shelf life. Among the storage structures so far evaluated at Bako, mud blockate storage, above ground storage (circular form of mat), simple silo of land constructed above the ground (investigated by Holeta research center) resulted in low percent weight of damaged tubers, lower percent weight of tubers produce sprout and higher percent weight of normal tubers. The period of protection lasted for about four (4) months at the experimental conditions and recommended for the end users.

\section{Acknowledgement}

I am very grateful to Crop Protection Research Division field assistance and field supervisor for their immeasurable and wholehearted efforts they made in managing the field. My special thanks go to Tadesse Birhanu for their enthusiastic efforts they made in collecting the data.

\section{Conflict of Interest}

Conflict of interest none declared.

\section{REFERENCES}

Adhanom Negasi., Tsedeke Abate and Emana Getu (1985). Research on insect pest of root and tuber crops in Ethiopia,Tsedeke A (ed ) pro. First Ethiopian crop protection Symposium, Addis Ababa, Ethiopia.

Anonymous (1980). Annual report of international potato center,CIP Lima ,Peru.

Palecios, M. and Cisnerose, F. (1997). International potato center. Integrated pest management for the potato tuber moth in pilot units in the Anden Region and Domin- ica Republic Lima Peru.

Smith (1977). Effect of storage on specific gravity of tubers and quality of cooked and processed potatoes. Potato production, storing, processing. United state of America, p, 436-69.

Solomon Yilma (1985). Review of potato research in Ethiopia. First Ethiopian horticultural work shop, p, 294. Institute of Agricultural Research (IAR). Addis Ababa, Ethiopia.

Tindal, H.D. (1983). Potato preparation for market and storage. Vegetable in tropics, Hong Kong, 375-76.

Varlag P.P. (1973). Crop pest in Tanzania and their control. D-1000 Berlin 61, Lindenstrasse 44-47, D-2000 Hamburg, Spitaler strasse 12, W. Germany. 